\title{
Effect of Graded Levels of Sulphur as Magnesium Sulphate on Yield and Quality of Onion (Allium cepa L.) in Red and Lateritic Soils of West Bengal, India
}

\author{
Shreya Mondal ${ }^{1}$, G. K. Ghosh ${ }^{1}$ and Joydip Mandal ${ }^{2}$ \\ ${ }^{1}$ Department of Soil science and Agricultural Chemistry, Palli Siksha Bhavan, Institute of \\ Agriculture, Visva Bharati, Sriniketan-731236, Dist-Birbhum, West Bengal, India \\ ${ }^{2}$ Department of Horticulture, Palli Siksha Bhavan, Institute of Agriculture, Visva Bharati, \\ Sriniketan -731236,Dist-Birbhum, West Bengal, India \\ *Corresponding author
}

Keywords

Red and lateritic soils, Sulphur, Magnesium sulphate, Reducing sugar, Total sugar, TSS

Article Info

Accepted:

22 March 2020

Available Online:

10 April 2020

\begin{abstract}
A B S T R A C T
Onion is a very important commercial vegetable crop in the kitchens of India. Sulphur is an important nutrient that affects the yield and quality of onion. Keeping this in view an experiment was conducted to study the effect of graded levels of sulphur on yield and quality of onion at Horticultural Research Farm of Institute of Agriculture, Visva-Bharati, Sriniketan, India. The treatments consisted seven incremental doses of sulphur viz. 0, 10, 20, 30, 40, 50 and $60 \mathrm{~kg} \mathrm{~S}^{-1}$ as magnesium sulphate in a randomized block design with three replications. Yield attributes responded favourably to the sulphur application in the range of 40-50 kg ha-1. Maximum bulb yield $\left(28.52 \mathrm{t} \mathrm{ha}^{-1}\right)$ of onion was recorded with 40 $\mathrm{kg} \mathrm{S} \mathrm{ha-}{ }^{-1}$. Nutrient uptake by bulb was also found maximum in the sulphur application of $40 \mathrm{~kg} \mathrm{ha}^{-1}$. Maximum pyruvic acid, reducing sugar and total sugar was registered in application of sulphur @ $40 \mathrm{~kg} \mathrm{ha}^{-1}, 40-50 \mathrm{~kg} \mathrm{ha}^{-1}$ and $60 \mathrm{~kg} \mathrm{ha}^{-1}$ respectively. Total soluble solids (TSS) did not have any significant variation among the treatments. Results revealed that onion responded well with sulphur as magnesium sulphate and application of sulphur@40 kg S ha ${ }^{-1}$ is helpful in augmenting the higher productivity and better quality of onion in sulphur deficient red and lateritic soils of West Bengal, India.
\end{abstract}

\section{Introduction}

Onion (Allium cepa) is an important vegetable belonging to family Alliaceae. It is an indespensible item in every kitchen as vegetable and condiment used to flavor many of the food stuffs. Therefore, onion is popularly referred as "Queen of Kitchen" (Selvaraj, 1976). Its pungency is mainly due to Allyl propyl disulphide, a volatile oil. Onion (Allium cepa) is a sulphur loving plant and sulphur is a major essential nutrient for plants, required for proper growth, yield and quality of onion (Kumar and Singh, 1995). 
Sulphur has been found not only to increase the bulb yield of onion but also improves its quality, especially pungency and flavours (Jaggi and Dixit, 1999). Bell (1981) also reported sulphur containing secondary compounds was not only of importance for nutritive value and flavours, but also for resistant against pests and diseases.

Sulphur deficiencies have been reported from over 70 countries worldwide including India. Sulphur deficiencies in India are widespread and scattered throughout 120 districts out of 400 districts (Tandon 1991). Deficiency of sulphur in Indian soils is on increase due to intensification of agriculture with high yielding varieties and multiple cropping coupled with the use of high analysis sulphur free fertilizers along with the restricted or no use of organic manures have accrued in depletion of the soil sulphur reserve.

Crops generally absorb sulphur and phosphorus in similar amounts. In West Bengal Red and Lateritic soils occupy about 28 per cent of the total geographical area of the state (Anon. 1989).

Of these, red soil occur in the districts of Birbhum, Bankura, Burdwan, Midnapore and some other parts of Malda and West Dinajpur and gravelly soils are found in the districts of Purulia, part of Midnapore, Bankura and Birbhum (Mandal and Roy 1985). Some parts of Birbhum, Burdwan, Bankura, and Midnapore have also laterites and lateritic soils (Panda et al., 1991).

In fact, the red, laterite and associated soils of Eastern India are acidic in soil reaction, light textured, low in organic matter and $\mathrm{P}$ and are often deficient in S (Panda et al., 1991, Sakal and Singh 1997). In West Bengal, six districts viz. Birbhum, Burdwan, Murshidabad, Midnapore, Nadia and 24 Parganas have been reported to be sulphur deficient (Tandon
1991). A considerable area of West Bengal is sulphur deficient or likely to become deficient except for the coastal and saline soils. It has been observed that the intensity of $S$ deficiency in red and lateritic soils of different blocks of Birbhum district of West Bengal ranged from about 21 to $40 \%$ with an average of $28 \%$ as per critical value approach and 25 to $41 \%$ with an average of $31 \%$ as per sulphur availability index (SAI) (Chattopadhayay et al., 2006).

India ranks second in global onion production after China and with an annual production of 16 to 17 million tonnes accounts for around $20 \%$ of global production (FAO, 2010). However, Indian onion yield is one of the lowest. The total production of onion during the year 2015-16 is estimated at around 202.14 lakhs MT as per the 2nd advance estimates.

Out of this, around $65 \%$ produce which comes in rabi season is partly used for domestic consumption as well as storage for further consumption in different parts of the country. The major onion storing states are Maharashtra, Gujarat, Madhya Pradesh, Rajasthan and Bihar.

\section{Materials and Methods}

The field experiment on onion cultivar of Sukhsagar was conducted in rabi season of 2015-16 in the months of December to March at the Horticultural farm of Palli Sikhsha Bhavana (Institute of Agriculture), Visva Bharati, Sriniketan, West Bengal, India (situated at $23^{\circ} 39^{\prime} \mathrm{N}$ latitude and $87^{\circ} 42^{\prime} \mathrm{E}$ longitude ).

The crop was planted (spacing of $15 \mathrm{~cm} \times 10$ $\mathrm{cm}$ ), fertilized and irrigated as per the recommended practices. Before fertilizer application, random soil samples were taken from the experimental site and were analyzed. 
The analysis revealed that initial soil was acidic in nature ( $\mathrm{pH}$ 6.32) and contains 25.1 $\mathrm{kg} \mathrm{ha}^{-1} \mathrm{~N}, 11.2 \mathrm{~kg} \mathrm{ha}^{-1} \mathrm{P}, 147.8 \mathrm{~kg} \mathrm{ha}^{-1} \mathrm{~K}$, $10.5 \mathrm{~kg} \mathrm{ha}^{-1} \mathrm{~S}$ and $0.32 \%$ organic carbon. The experiment was laid out in randomized block design with three replications and with incremental doses of Sulphur $(0,10,20,30$, 40,50 and $\left.60 \mathrm{~kg} \mathrm{ha}^{-1}\right)$. The source of sulphur was magnesium sulphate. Sulphur fertilizer was given as basal and other fertilizers were given in split applications. Different growth parameters were observed on 5 plants per plots at 30 days interval. After harvest of onion different chemical analysis were carried out on both soil and bulb.

Quality parameters viz. pyruvic acid, reducing sugar, total sugar and TSS were estimated as per standard procedures. Nutrient uptake was analysed both in soil and plant sample of Nitrogen, Phosphorous, Potassium by standard procedure. Available sulfur in the soil was extracted using $0.15 \%$ calcium chloride $\left(\mathrm{CaCl}_{2}\right)$ solution (Williams and Steinbergs, 1959). Sulphur content in bulb was determined after wet digestion in diacid mixture of nitric acid $\left(\mathrm{HNO}_{3}\right)$ and perchloric acid at a ratio of 4:1 as per Jackson (1973).

Sulphur content in the digest of plant extract was determined using turbidimetric method of Chesnin and Yien (1951) by turbidimetric method by using spectrophotometer at 440 nm (Jackson, 1967). Yield was calculated in quintal per hectare and other yield attributes like bulb polar and equatorial diameter and average bulb weight was calculated.

Statistical analyses were carried out following the method of analysis of variance (ANOVA). For comparisons between treatment means, standard error of the mean difference $(\mathrm{Sd})$ and least significant difference (LSD) at $\alpha=0.05$ level of significance were calculated (Gomez and Gomez, 1984).

\section{Results and Discussion}

\section{Growth parameters}

Plant height for treatment $30 \mathrm{~kg} \mathrm{ha}^{-1}$ was found more in 30DAT while it was more in treatment $20 \mathrm{~kg} \mathrm{ha}^{-1}$ in 60DAT AND 90 DAT. Jana and Jahangir (1990) obtained highest plant height with sulphur @ $30 \mathrm{~kg} \mathrm{ha}^{-1}$. Sharma et al., (2002) reported that plant height increased with increase in $S$ rate upto $30 \mathrm{~kg} \mathrm{ha}^{-1}$ in heavy textured soils and upto $45 \mathrm{~kg} \mathrm{ha}^{-1}$ in light textured soils (Fig. 1).

Nagaich et al., (1999) reported that application of sulphur @ 60 kg ha ${ }^{-1}$ significantly increased plant height. Plant height was found least in $60 \mathrm{~kg} \mathrm{ha}^{-1}$ treatment in all through growing period of crop. Plant height declined significantly at higher rate of sulphur application $\left(60 \mathrm{~kg} \mathrm{ha}^{-1}\right)$. These results may be related to the benefits of adequate $S$ supplies to the plants, because low or excessive doses are detrimental to growth and development.

Maximum leaf number is noted mainly between 30 to $50 \mathrm{~kg} \mathrm{ha}^{-1}$ application of sulphur. Increase in leaf number with application of sulphur was also reported by Nagaich et al., (1999), Jaggi (2005) and Tripathy et al., (2013) (Fig. 2).

Leaf length for treatment $40 \mathrm{~kg} \mathrm{ha}^{-1}$ was found more in 30DAT, 60DAT and 90 DAT. Thus, maximum leaf length is noted mainly between 20 to $50 \mathrm{~kg} \mathrm{ha}^{-1}$ application of sulphur. Suman et al., (2002) reported that leaf length increased upto $40 \mathrm{~kg} \mathrm{~S}$ per hectare (Fig. 3).

Leaf diameter for treatment $40 \mathrm{~kg} \mathrm{ha}^{-1}$ was found more in 30DAT, treatment $20 \mathrm{~kg} \mathrm{ha}^{-1}$ in 60DAT and $30 \mathrm{~kg} \mathrm{ha}^{-1}$ in 90 DAT. Leaf diameter was found least in $0 \mathrm{~kg} \mathrm{ha}^{-1}$ treatment in all through growing period of crop (Fig. 4). 
Neck length for treatment $40 \mathrm{~kg} \mathrm{ha}^{-1}$ was found more in 30DAT, treatment $60 \mathrm{~kg} \mathrm{ha}^{-1}$ in 60DAT and $20 \mathrm{~kg} \mathrm{ha}^{-1}$ in 90 DAT. A constant increase in all growth parameters is seen through the cropping period from 30DAS to 90 DAT (Fig. 5).

Data on plant for $30,60,90$ DAT is given in figure 6 . Neck diameter for treatment $30 \mathrm{~kg}$ $\mathrm{ha}^{-1}$ was found more in 30DAT ,60DAT and 90 DAT. Neck diametre was found minimum in $0 \mathrm{~kg} \mathrm{ha}{ }^{-1}$ treatment in all through growing period of crop. Tripathy et al., (2013) reported significant variations among the graded levels of sulphur application in onion. Kumar et al., (1998) reported that sulphur application increased neck diameter in onion. On the contrary, Mishu et al., (2013) reported neck diameter was not significantly affected by different doses of sulphur application.

\section{Yield and yield attributes}

The effect of graded levels of sulphur on yield and yield attributes of onion are presented in Table 1. Both polar and equatorial diameter play an important role in determining the shape and size of onion bulb. Significantly higher polar and equatorial diameter was registered due to application of sulphur @ 40 to $50 \mathrm{~kg} \mathrm{ha}^{-1}$. Similar result has also been reported by Jana and Kabir (1990). Nagaich et al., (1999) and Tripathy et al., (2013) also reported that application of sulphur significantly increased the equatorial diameter. No sulphur application was found comparatively less polar and equatorial diameter. Nagaich et al., (1999) reported that polar diameters increased with sulphur application@60kg ha ${ }^{-1}$ over control plots.. Bulb weight of onion significantly increased with application of sulphur over no application. Highest bulb weight was observed with application of sulphur at the range of 30 to $50 \mathrm{~kg} \mathrm{ha}^{-1}$. Increase in bulb weight with increasing rates of sulphur was reported by a number of researchers (Jana and Jahangir, 1990; Nagaich et al., 1999; Jaggi 2005 and Mishu et al., 2013). Yield is the main parameter which is considered important for all field experiment undertaken. In this experiment, it is noted that onion yield increased significantly with application sulphur over control plot (without sulphur application). De Souza et al., (2015) reported that onion productivity was $16 \%$ lower in no sulphur application plot. It was also noted that graded levels of sulphur application linearly increased the bulb yield of onion up to $40 \mathrm{~kg}$ $\mathrm{ha}^{-1}\left(28.52 \mathrm{t} \mathrm{ha}^{-1}\right)$ which was also observed by Jaggi and Raina (2008).

\section{Quality parameters}

Figure 7 gives the observation regarding effect of graded levels of sulphur on quality parameter of onion. The quality of onion depends on its pungency and total soluble solids. The pyruvic acid content of onion bulbs is associated with its pungency. In this experiment maximum pyruvic acid content in onion bulbs was noticed in sulphur application at 40 and $50 \mathrm{~kg} / \mathrm{ha}$. It was found that pyruvic acid was least in control plot with no sulphur application and increased linearly upto 40 and $50 \mathrm{~kg} \mathrm{ha}^{-1}$ and decreased with $60 \mathrm{~kg} \mathrm{ha}^{-1}$ sulphur application.

Forney et al., (2002) and Thangasamy et al., (2013) also find that the pyruvic acid content had significant and positive correlation with sulphur application. Maximum pungency was reported with sulphur application of $60 \mathrm{~kg} \mathrm{ha}^{-1}$ (Channagaoudar and Janawade, 2006), $65 \mathrm{~kg}$ $\mathrm{ha}^{-1}$ (de Souza et al., 2015), $75 \mathrm{~kg} \mathrm{ha}{ }^{-1}$ (Quereshi and Lawande, 2006), 160kg ha ${ }^{-1}$ (Shakirullah et al., 2002).Total soluble solids (TSS) is an important biochemical parameter that determines quality of onion. Experimental data determines that TSS does not have any significant effect on onion. 
Reducing sugar was found maximum in plots with sulphur application of 40 and $50 \mathrm{~kg} \mathrm{ha}^{-1}$. Minimum reducing sugar was found in control plots with no sulphur application. Reducing sugar was found to be increasing from control plots upto 40 and $50 \mathrm{~kg} \mathrm{ha}^{-1}$ and decreased in sulphur application of $60 \mathrm{~kg} \mathrm{ha}^{-1}$. Total sugar was found significantly increasing from control plot with no sulphur to sulphur application at $60 \mathrm{~kg} \mathrm{ha}^{-1}$ having maximum total sugar.

\section{Nutrient concentration in onion bulb after harvest}

As per the data obtained in dry matter it was found that total nitrogen is maximum in the range between 40 to $60 \mathrm{~kg} \mathrm{~S} \mathrm{ha}{ }^{-1}$ and minimum total nitrogen was found in $10 \mathrm{~kg} \mathrm{~S}$ $\mathrm{ha}^{-1}$ having an increasing trend with increasing levels of sulphur application ranging from $1.03 \%$ to $1.79 \%$. Nasreen et al., (2007) found almost a liner increase in $\mathrm{N}$ uptake with the increased rate of sulphur application upto $40 \mathrm{~kg} \mathrm{~S} \mathrm{ha}{ }^{-1}$ and further increase in sulphur application decreased the $\mathrm{N}$ uptake. Both Phosphorous and potassium uptake was found to have increased upto $40 \mathrm{~kg}$
$\mathrm{S} \mathrm{ha}^{-1}$ with highest nutrient content in $60 \mathrm{~kg} \mathrm{~S}$ $\mathrm{ha}^{-1}$. Sulphur content in dry matter increased upto $50 \mathrm{~kg} \mathrm{~S} \mathrm{ha}^{-1}$ but slightly decreased in sulphur application of $60 \mathrm{~kg} \mathrm{~S} \mathrm{ha}{ }^{-1}$ and minimum sulphur uptake was found in control plot with no sulphur application. Sulphur concentration in onion was found highest in sulphur application @40-60 kg ha ${ }^{-1}$ ranging from $0.89 \%$ to $0.9 \%$. Significant treatment effects were found in nutrient concentration and uptake by bulb.

\section{Soil properties and available nutrient content in soil after harvest}

Data regarding $\mathrm{pH}, \mathrm{EC}$ and organic carbon has been presented in table 2 . There has been a decreasing trend in $\mathrm{pH}, \mathrm{EC}$ and organic carbon from control plots to plots with sulphur application of $60 \mathrm{~kg} \mathrm{ha}^{-1}$. Available phosphorous was found maximum in sulphur application of $20 \mathrm{~kg} \mathrm{ha}^{-1}$. Available sulphur was found gradually increasing from no sulphur application to sulphur application of $60 \mathrm{~kg} \mathrm{ha}^{-1}$. Maximum available sulphur was found in soils with sulphur application of $60 \mathrm{~kg} \mathrm{ha}^{-1}$. There were significant treatment effects among the available soil nutrients.

Table.1 Effect of graded levels of sulphur on yield and yield attributes of onion

\begin{tabular}{|c|c|c|c|c|}
\hline \multirow{2}{*}{ Treatments } & \multicolumn{2}{|c|}{ Bulb diameter $(\mathbf{m m})$} & Average bulb & Yield \\
& Polar & Equatorial & weight $\mathbf{( g )}$ & (t/ha) \\
\hline $\mathbf{S}_{\mathbf{0}}$ & 41.4 & 53.9 & 47.6 & 21.83 \\
\hline $\mathbf{S}_{\mathbf{1 0}}$ & 42.1 & 54.2 & 48.3 & 22.82 \\
\hline $\mathbf{S}_{\mathbf{2 0}}$ & 43.1 & 56.2 & 51.8 & 23.91 \\
\hline $\mathbf{S}_{\mathbf{3 0}}$ & 44.5 & 55.5 & 60.7 & 25.38 \\
\hline $\mathbf{S}_{\mathbf{4} 0}$ & 50.1 & 59.2 & 59.5 & 28.52 \\
\hline $\mathbf{S}_{\mathbf{5 0}}$ & 46.8 & 57.8 & 59.7 & 25.66 \\
\hline $\mathbf{S}_{\mathbf{6 0}}$ & 44.0 & 53.0 & 53.9 & 25.25 \\
\hline $\mathbf{M e a n}$ & 44.6 & 55.7 & 54.5 & 24.77 \\
\hline $\mathbf{S . E m}(\mathbf{\pm})$ & 1.3 & 1.2 & 2.9 & 1.1 \\
\hline $\mathbf{C D}$ & 3.9 & 3.8 & 8.8 & 3.3 \\
\hline $\mathbf{C V}$ & 5.0 & 3.8 & 9.1 & 7.5 \\
\hline
\end{tabular}


Table.2 Effect of graded levels of sulphur on soil properties and available nutrient content $(\mathrm{kg} / \mathrm{ha})$ by soil after harvest of onion

\begin{tabular}{|c|c|c|c|c|c|c|c|}
\hline Treatments & $\mathbf{p H}(\mathbf{1 : 2})$ & $\begin{array}{c}\mathbf{E C} \\
\mathbf{d s m}^{-\mathbf{1}} \mathbf{)}\end{array}$ & $\begin{array}{c}\text { Organic } \\
\text { carbon }(\mathbf{\%})\end{array}$ & Avl. N & Avl. P & Avl. K & Avl. S \\
\hline $\mathbf{S}_{\mathbf{0}}$ & 6.01 & 0.45 & 0.35 & 83.6 & 16.8 & 211.1 & 0.5 \\
\hline $\mathbf{S}_{\mathbf{1 0}}$ & 5.63 & 0.46 & 0.22 & 133.7 & 15.0 & 298.5 & 1.1 \\
\hline $\mathbf{S}_{\mathbf{2 0}}$ & 5.32 & 0.46 & 0.23 & 140.4 & 17.8 & 193.2 & 2.2 \\
\hline $\mathbf{S}_{\mathbf{3 0}}$ & 5.32 & 0.45 & 0.18 & 167.3 & 16.2 & 176.4 & 2.0 \\
\hline $\mathbf{S}_{\mathbf{4 0}}$ & 5.35 & 0.46 & 0.22 & 200.7 & 12.0 & 404.3 & 3.2 \\
\hline $\mathbf{S}_{\mathbf{5 0}}$ & 5.35 & 0.42 & 0.20 & 234.2 & 14.6 & 239.7 & 5.5 \\
\hline $\mathbf{S}_{\mathbf{6 0}}$ & 5.25 & 0.41 & 0.15 & 334.5 & 14.0 & 222.9 & 13.8 \\
\hline $\mathbf{M e a n}_{\mathbf{S E m}(\mathbf{\pm}}$ & 5.46 & 0.44 & 0.22 & 184.9 & 15.2 & 249.4 & 4.0 \\
\hline $\mathbf{C D}$ & 0.16 & 0.02 & 0.02 & 3.5 & 0.2 & 3.017 & 0.3 \\
\hline $\mathbf{C V}(\mathbf{\%})$ & 0.49 & 0.06 & 0.06 & 10.8 & 0.7 & 9.294 & 0.8 \\
\hline & 5.07 & 7.21 & 14.94 & 3.3 & 2.6 & 12.09 & 11.1 \\
\hline
\end{tabular}

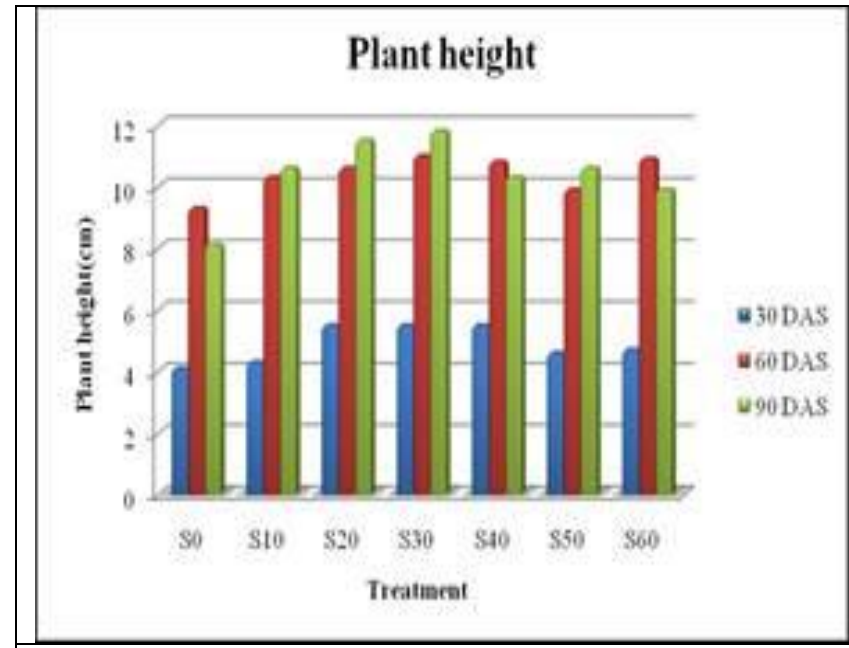

Fig.1 Effect of graded levels of sulphur on plant height of onion

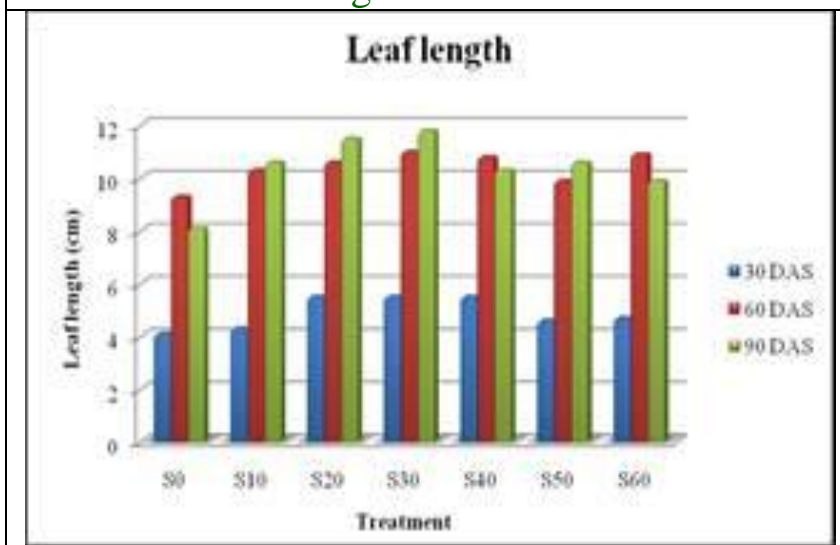

Fig.3 Effect of graded levels of sulphur on leaf length of onion

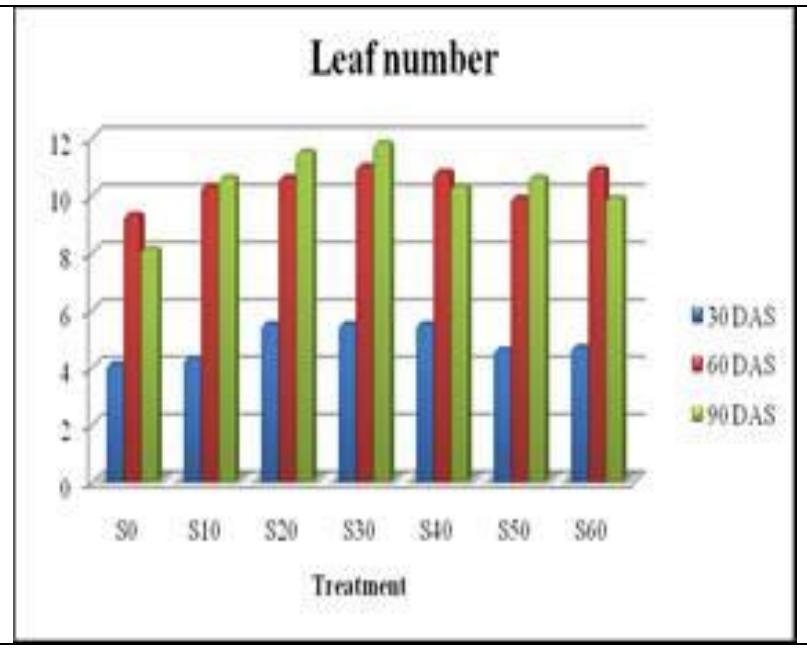

Fig.2 Effect of graded levels of sulphur on leaf number of onion

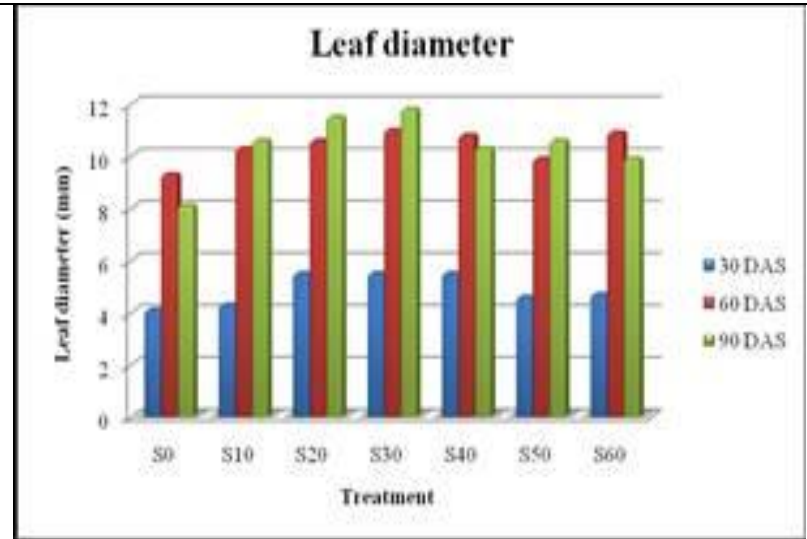

Fig.4 Effect of graded levels of sulphur on leaf diameter of onion 

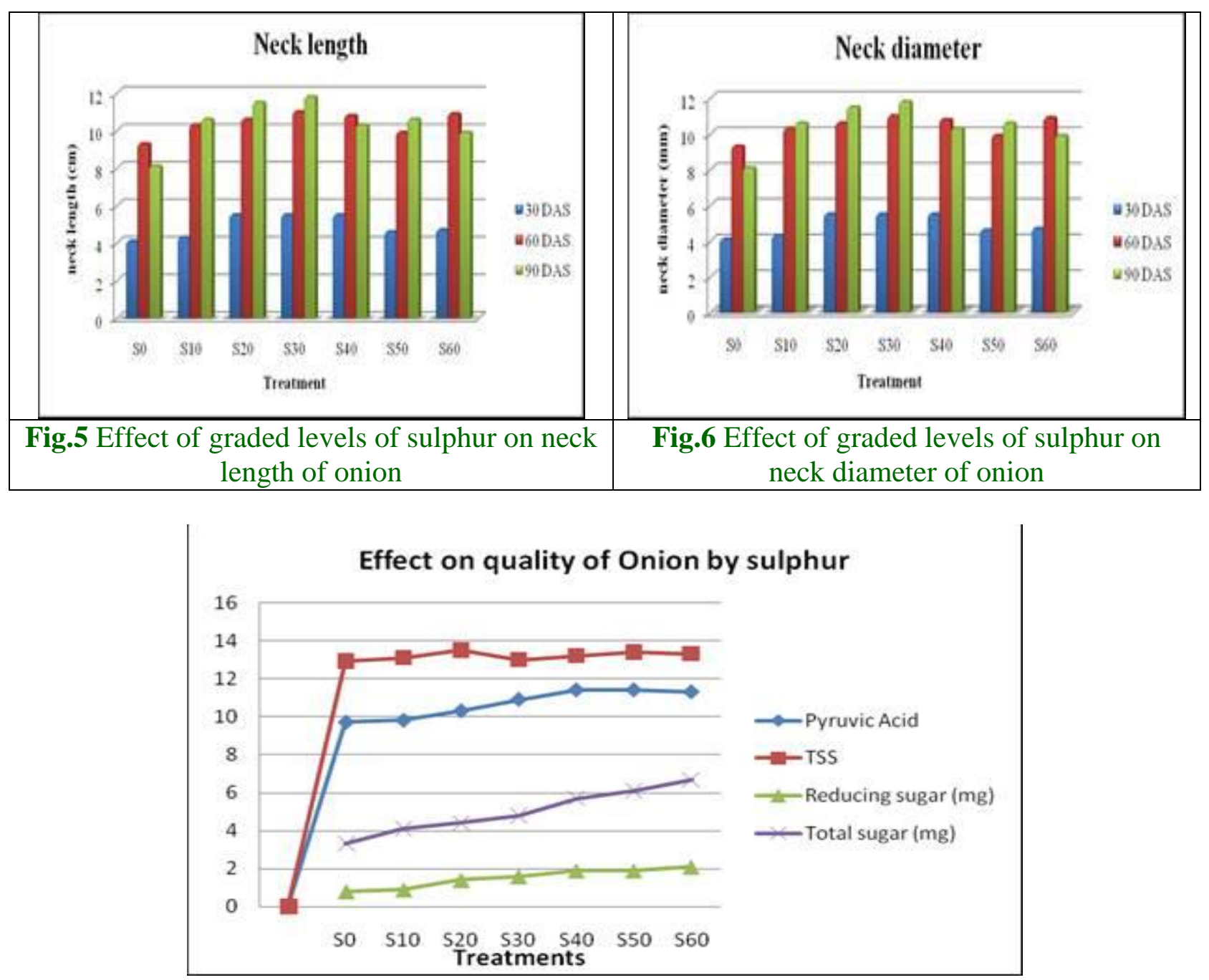

Fig.7 Effect of graded levels of sulphur on quality and biochemical content in onion bulb

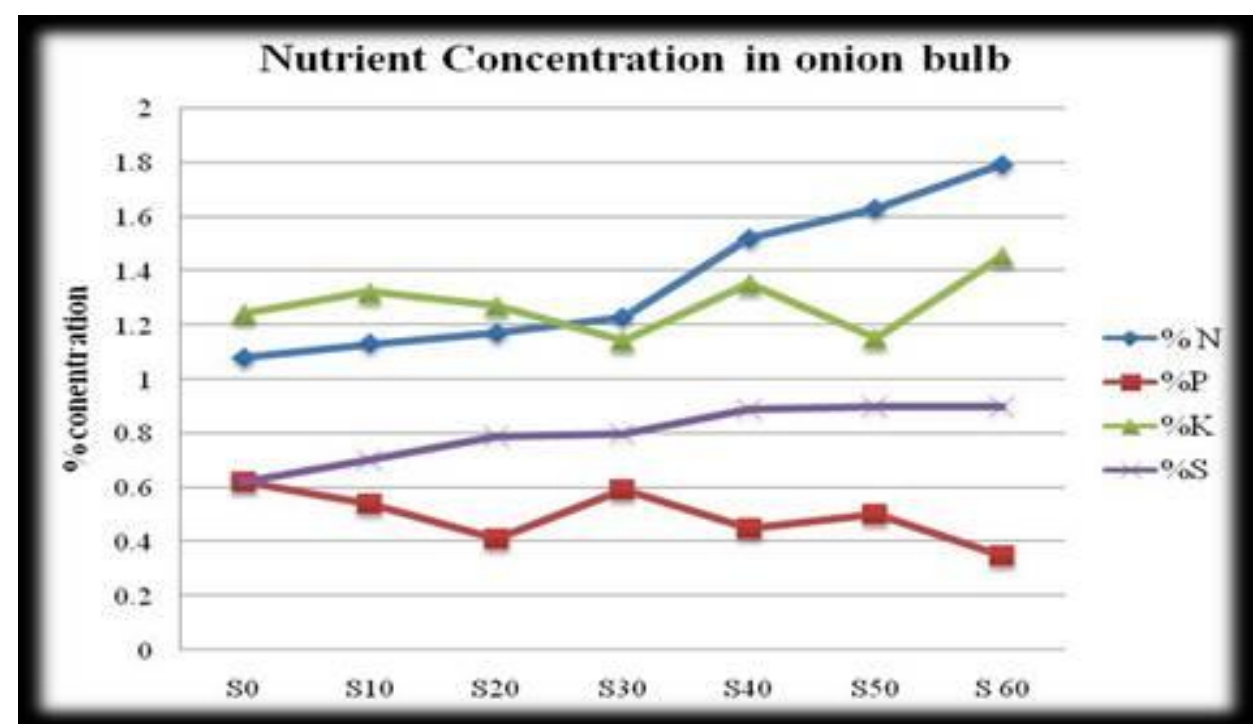

Fig.8 Effect of graded levels of sulphur on nutrient concentration in onion bulb 
Thus, from the above results it can be concluded that the red and lateritic soils of the region are very much responsive to sulphur application. Results also suggest that application of sulphur @ $40 \mathrm{~kg} \mathrm{~S} \mathrm{ha}^{-1}$ is helpful in augmenting the higher productivity and better quality of onion in sulphur deficient red and lateritic soils of West Bengal.

\section{References}

Ajay, K., Singh, O., 1994. Role of sulphur in nutrient utilization and catalase activity in onion crop. Indian Journal of Agricultural Research 28, 15-19.

Channagoudar, R.F and Janawade, A.D., 2006; Effect of Different Levels of Irrigation and Sulphur on Growth, Yield and Quality of Onion (Allium cepa L.). Karnataka Journal of Agric. Sci.,19(3): 489-492

Channagoudar, R.F., Ajjappalavara, P., Kamble, A.S., 2009. Response of onion (Allium cepa L.) to different levels of irrigation and sulphur in alfisoils of northern transitional tract of Karnataka. The Asian Journal of Horticulture; 4(1), 152-155.

Chattopadhayay S. and Ghosh, G.K.,2006. Sulphur Status soils in red and lateritic soils of Birbhum district of West Bengal. Indian Journal of fertilizers, 2(2): 35-38.

De Souza, L.F.G., Filho, A.B.C., deTulio, F.A. and Nowaki, R.H.D.(2015) Effect of sulphur dose on the productivity and quality of onions. Australian Journal of Crop Sciences, 9, 728-33.

Dudhat, M.S., Chovatia, P.K., Sheta, B.T., Thesiya, N.M., 2011. Effect of sources and levels of sulphur fertilizers on bulb yield of onion (Allium cepa L.). International Journal of Plant Sciences; 6(1), 134-136.

Hasan Mahmud Mishu, Fahim Ahmed, M. Y.
Rafii, Faruq Golam, and M. A. Latif (2013). Effect of sulphur on growth, yield and yield attributes in onion (Allium cepa L.). Australian Journal of Crop Science, 7(9), 1416-1422.

Jaggi, R.C. and Dixit, S.P. (1999) Onion (Allium cepa L.) responses to sulphur in representative vegetable growing soils of Kangra Valley of Himachal Pradesh. Indian Journal of Agricultural Science, 69, 289-291.

Jaggi,R.C.(2005) Sulphur levels and sources affecting yield and yield attributes in onion (Allium cepa) .Indian Journal of Agriculture Science, 75, 154-56.

Kumar, A., Singh, O., 1995. Effect f sulphur deficiency on plant growth and yield in onion. Indian Journal of Agricultural Research; 29(3), 127-130.

Meena O.S. and D. Singh (1998). Effect of sulphur and zinc application on onion yield and sulphur and zinc uptake in three Soil Orders. Journal of the Indian Society of Soil Science, 46 (4): 636-640.

Nagaich, K.N., Trivedi, S.K. and Lekhi, R. (1999) Effect of sulphur and potassium fertilization in onion (Allium cepa). Horticure Journal, 12, 25-31.

Nasreen ,Shamima and ImamulHuq, S.M. (2005) Effect of sulphur fertilization on yield, sulphur content and uptake by onion. Indian Journal of Agricultural Research, 39(2), 122-125.

Patra, P., Mondal, S. and Ghosh, G.K.,2012. Status of available sulphur in surface and sub-surface soils of red and lateritic soils of West Bengal. International Journal of Plant Animal Environment Science, 2: 276-81.

Raina, S.K. and Jaggi, R.C. (2008) Effect of presence and absence of Farm Yard Manure on onion (Allium cepa) cropping sequence. Indian journal of Agriculture Science., 78,659-62.

Shakirullah, Mohammad, Ishtiaq, Roshan, Ali and S.I.H. Shah (2002). Effect of 
different levels of sulphur on yield and pungency of onion. Sarhad Journal of Agriculture, 18(2), 183-187.

Suman,Smriti, Kumar Rajesh and S.K. Singh (2002). Effect of sulphur and boron nutrition on growth, yield and quality of onion (Allium cepa L.). Journal of Applied Biology, 12 (1-2): 40-46.

Thangasamy, A., Sankar, V. and Lawande, K.E. (2013) Effect of sulphur nutrition on pungency and storage life of short day onion. Indian Journal of Agriculture Sci., 83, 1086-89. Tripathy, P., Sahoo, B.B., Priyadarshini, A, Das, S.K. and Dash, D.K. (2013) Effect of Sources and Levels of Sulphur on Growth, Yield and Bulb Quality in Onion (Allium cepa L.). International Journal of Bio-resource and Stress Management, 4(4), 641-644

\section{How to cite this article:}

Shreya Mondal, G. K. Ghosh and Joydip Mandal. 2020. Effect of Graded Levels of Sulphur as Magnesium Sulphate on Yield and Quality of Onion (Allium cepa L.) in Red and Lateritic Soils of West Bengal, India. Int.J.Curr.Microbiol.App.Sci. 9(04): 2858-2866.

doi: https://doi.org/10.20546/ijcmas.2020.904.335 